\title{
The conduct of history in International Relations: rethinking philosophy of history in IR theory
}

\author{
JOSEPH MACKAY ${ }^{1}$ and CHRISTOPHER DAVID LAROCHE ${ }^{2}$ \\ ${ }^{1}$ Postdoctoral Fellow, Harriman Institute, Columbia University, New York, NY, United States of America \\ ${ }^{2} \mathrm{PhD}$ Candidate, Department of Political Science, University of Toronto, Toronto, ON, Canada
}

E-mail: joseph.mackay@utoronto.ca

\begin{abstract}
IR scholars have made increasingly sophisticated use of historical analysis in the last two decades. To do so, they have appealed to theories or philosophies of history, tacitly or explicitly. However, the plurality of approaches to these theories has gone largely unsystematized. Nor have their implications been compared. Such historical-theoretic orientations concern the 'problem of history': the theoretical question of how to make the facts of the past coherently intelligible. We aim to make these assumptions explicit, and to contrast them systematically. In so doing, we show theories of history are necessary: IR-theoretic research unavoidably has tacit or overt historical-theoretic commitments. We locate the field's current historical commitments in a typology, along two axes. Theories of history may be either familiar to the observer or unfamiliar. They may also be linear, having a long-term trajectory, nonlinear, lacking such directionality, or multilinear, proceeding along multiple trajectories. This comparative exercise both excavates the field's sometimes-obscured commitments and shows some IR theorists unexpectedly share commitments, while others unexpectedly do not. We argue that better awareness of historical-theoretic reasoning, embedded in all IR uses and invocations of history, may encourage the discipline become more genuinely plural.
\end{abstract}

Keywords: IR theory; history; philosophy of history; foundations

'Theory precedes history'

$$
\text { (Raymond Aron). }{ }^{1}
$$

This essay recovers the role of theories or philosophies of history in International Relations (IR) theory. In the last two decades, IR has made more and better use of history. In so doing, IR scholars have turned - or, more accurately, returned - to theories of history. This theoretical work has been intellectually productive, but to date has gone under-documented

${ }^{1}$ Quoted in Ricoeur $(1965,26)$. 
and unsystematized. This essay aims to remedy this, casting systematic light on the theoretical turn within the historical turn. Insofar as IR theorists explicitly or implicitly mobilize systematic accounts of history to justify their claims, we argue that philosophy of history is both necessary and desirable for the development of IR theory. In doing so, they necessarily make assumptions about how history works on a large scale. Such assumptions aim to address the 'problem of history': the theoretical question of how to make the past systematically intelligible. We find such thought already at work in much, indeed most IR theory. In explicating it, we aim to excavate the range of historical-theoretic possibilities available to the discipline. ${ }^{2}$ We call for an attitude of pluralism toward such approaches.

The current revival of interest in history is important in part because it reengages the field with a long and deep tradition of historical-theoretic thought. Canonical views of world politics, including realism, liberalism, Marxism, and others, once explicitly addressed the problem of history, articulating or relying upon arguments about history's underlying intelligibility and often placing those arguments at the centers of their respective claims about politics. Indeed, some canonical IR theorists (Aron 1976; Carr 2001b) once viewed history itself as an object needing theoretical inquiry. Exceptionally, constructivist and critical approaches have recently revived interest in philosophy of history. But for the last several decades, mainstream North American IR scholars have not always made their assumptions about history explicit, despite relying tacitly on history for their theories. This has led to misrepresentations, poorly framed disagreements, and neglect of a central component of the field's foundations. These shortcomings can best be addressed by making clear the stakes and range of possibilities for historical theory in IR.

We aim more specifically to redirect attention toward theory or philosophy of history. Philosophers of history concern themselves not only with technical matters of historiographical method, but also more generally with foundational questions about the long-run form of human history as such, and historians' basis for claims to knowledge of it. Such basic questions orient more specific methodological questions about the writing of particular histories. Thus, they also underlie IR's usage of specific written histories and historical events in its theorizing. Like structures, philosophies

2 This paper thus builds on IR's disciplinary self-examinations of the last two decades. The 'paradigm wars' over rivalries between core schools of IR-theoretic thought have been largely supplanted by debate about the status of theory itself (Jackson and Nexon 2013) as scholars aim to transcend or reject traditional paradigms (Lake 2011), or dissolve core theoretical disagreements (Fearon and Wendt 2002). Pluralist understandings of social science have proliferated (Sil and Katzenstein 2010; Jackson 2011, 188-212). 
of history 'shape and shove' (Waltz 1997, 915) the theory building process, permitting and constraining views of how history itself works.

We argue that theories of history are necessary: the past cannot be systematically understood without the observer taking a theoretical stand in general terms on the form of history and our relationship to it. Theories of history are unavoidable. IR theorists necessary hold them, and should therefore make them explicit. We call for greater attention to theories of history, and specifically to their role in shaping IR theory itself. To do so, we develop a typology, emphasizing the plurality of historical-theoretic approaches at work in IR. We find approaches in six ideal-typical categories, which are located on two axes. We show that history can be theorized as linear, nonlinear, or multilinear, and as familiar or unfamiliar. That is, it may have a long-run trajectory, no trajectory, or a multiplicity of them. That trajectory may or may not be familiar, in the sense of knowable, to us as observers.

These categories make IR theory's sometimes-opaque historical gambits clearer, laying bare tacit disagreements and commonalities among major IR theories - some of them unexpected. We show, for example, that longstanding and well-known differences between neorealism and neoliberalism are rooted in the first instance not in disagreements about long- vs. short-run priorities, or absolute vs. relative gains, but instead in their respective historical-theoretic commitments. These views of history are not theoretical consequences of realism or liberalism, but instead preconditions for the coherence of those views. Elsewhere, we show some schools of IR-theoretic thought are internally divided: constructivisms and critical theories of various stripes deploy a striking range of historicaltheoretic assumptions. Even realism, which may appear the most internally coherent of IR-theoretic traditions, has prominent outliers. Elsewhere, recent efforts to recast the discipline as not just 'international' but 'global' in disposition (Acharya 2014) have been mirrored by scholars implying global politics entails a plurality of histories. We find these efforts promising, but nonetheless aim to incite greater self-reflection, on behalf of these scholars and others, concerning the field's many and varied historicaltheoretic wagers.

Our paper proceeds in five sections. In the first, we outline the problem of history and why it matters for IR scholarship. In the second, we briefly review core parallel debates in the philosophy of history, showing how they inform understandings of history's knowability. In a third section, we explain our typology, mapping mainstream IR theories onto it, and illustrating the permitting and constricting effect of historical theory on IR theory itself. Two additional sections explore the six types in detail. A conclusion explores theoretical implications. 


\section{International Relations and the problem of history}

IR scholars have traditionally developed theories by drawing on patterns of historical events, making assumptions about their underlying logic in so doing. Following terminology used in philosophical treatments of history, we term the resulting theoretical ambiguity the 'problem of history': in drawing conclusions about how events are related, scholars must impose theoretical assumptions about the form and comprehensibility of history on them. The problem pervades IR theory, but is not always recognized, and when it is, attention is rarely systematic. Aside from occasional invocations in criticism of opposing schools - as when realists (Mearsheimer 1994, 47-48) accuse liberals of harboring a narrative of progress - IR theory of the last several decades does little to systematically address the theories of history it implies. Constructivists and critical IR theorists recognize the problem of history in various forms. ${ }^{3}$ However, such considerations have often been absent from mainstream 'American school' IR scholarship (Levine and Barder 2014).

We define a theory of history at its most general level as the collection of assumptions (coherent or not) about the past that shapes the perspective from which historical inquiry can take place. A scholar's theory of history permits and constrains the conclusions he or she can draw about the past. Any theory based on history is necessarily linked to a theory of history. A given theory of history shapes the possibility, or impossibility, of social scientific prediction, informing the past's relation to the present and future. While theories of history are inherent in any systematic social inquiry, they seem especially pressing in IR, where matters of scope and scale - great power wars, systemic historical transitions - are at stake.

Some theories of history view the past as widely variable and the future thus as uncertain - as unfamiliar. Others treat the past as relatively static or as linearly progressive, and the future as a familiar extension of it. Others still see history as following a trajectory, but one knowable only retrospectively; only the past can be fully understood. Others yet again imagine a multiplicity of historical trajectories. Theories of history often posit long-run historical directions, such as the linear liberal movement toward globalization, the Marxist trajectory toward revolution, or the realist repetition of conflict. They also stipulate how intelligible history is to the observer. Such narratives are well known to IR theorists, but are not always understood on historical-theoretic terms. Indeed, the problem of history was once central to IR. The field's first major paradigm, realism, explicitly defined itself in opposition to the history-as-progress assumptions of liberal idealism, consciously articulating a historical-theoretic

\footnotetext{
${ }^{3}$ For a recent example and review, see Vaughan-Williams (2005) and Smith (2004).
} 
alternative (Carr 2001a; Niebuhr 2008). Only later did behavioralscientific IR submerge historical theory, relying nonetheless (as we show below) on tacit historical narratives.

We are now in the midst of a revival. A great deal of IR research, especially but not at all exclusively constructivist, has dealt with the historical record in recent years. ${ }^{4}$ Indeed, greater attention to the facts of history has increased interest in new grand theorizing based on the historical record (Donnelly 2009; Lebow 2009). Much of this research has been globally minded, reflecting interest in historical international structures outside the West (Buzan and Little 2000; Kang 2010; Phillips and Sharman 2015). A recent proliferation of literature on the uses of history is indicative of this trend. For example, Reus-Smit $(2008,414)$ locates the methodological basis of constructivist history in the Cambridge School approach to the history of political thought, giving rise to an approach 'that denies that a singular history of international relations is possible, acknowledges the scholar's role in constructing history, and recognises that explaining how ideas constitute agents and action requires us to situate them within culturally and historically specific contexts of argument and justification'. This is a methodological approach that does more than select and organize facts - it shapes the temporal arc of the world of which they form a part.

Constructivists are not alone. Lawson and his collaborators (Hobson and Lawson 2008; Lawson 2010; Buzan and Lawson 2015) have been concerned at length and in detail with historical methods in IR. A related revival of interest in historical sociology in IR (Hobden and Hobson 2002) might be understood as methodologically motivated, but also as something more. Like Reus-Smit, IR's historical sociology project commits its participants to a particular view of what it can tell us about world politics: on this account, the present is not a reliable model for the past, and international political orders are not 'isomorphic' over time. Put differently, the method of historical IR research is informed by the form of history as such: knowable, but nonstatic, a documentable process of change. Elsewhere, the genealogical approach of some IR scholars (Bartelson 1995; Molloy 2006) assumes a nonlinear past, composed of incidental and happenstance developments. Its historiographical methods are shaped a priori by Foucauldian, or Nietzschean, examinations of history's knowability - their philosophies of history.

4 These literatures are too large to survey. Prominent historical constructivists include ReusSmit (1999), Hall (1999), Philpott (2001), Bukovansky (2002), Nexon (2009), Mitzen (2013). Other examples range from Krasner's realism (1999), derived from early modern Europe, to Suzuki's (2009) English School account of Japan and China. 
A brief but telling recent exchange in International Studies Quarterly illustrates why theory of history matters. Buzan and Lawson (2013) argue that the 19th century constitutes a watershed period in the history of world politics. Musgrave and Nexon (2013) agree, but ask what theoretical form this watershed takes. It may belong to a general category: transformational periods in world history. Alternately, its very status as a historical turning point may make it unique, analogous to nothing before or after, because before and after are separated by transformation. Subsequent transformations would change the world uniquely again. The 19 th century, Musgrave and Nexon argue, would thus offer little basis for generalizing about other such processes. We argue these accounts assume different theories of history - understandings of how events are linked, and what long-haul knowledge of those linkages is possible.

The problem of history is underpinned by the problem of interpretation: that facts, rather than speaking for themselves, can only be made meaningful by theory (Taylor 1985; Kuhn 1996,1-9). History presents an acute variant of this issue, since it concerns facts as caught up in the passage of time, raising questions about their knowability. Since IR scholarship trades in the causes and effects of such large historical events and processes - war, peace, and transformations of the international system - it unavoidably invests in such accounts. Here, a terminological distinction may be useful. Tucker (2009) differentiates between the philosophy of history and the philosophy of historiography. The latter refers to philosophical matters regarding the conduct of professional historians - that is, methodological concerns about research on the past. The former term refers to philosophy as it bears on that discipline's object of study itself. Plainly, the two run together in important ways. Nonetheless, they constitute distinct, if somewhat overlapping, literatures.

A distinct but closely related emerging IR-theoretic literature concerns time and time perception. For example, Hutchings (2008) aims to show how public conceptions of temporality inform world political life. ${ }^{5}$ Hom (2010) links the emergence of 'Western standard time' to the rise of the sovereign state. Solomon (2013) links time to a psychoanalytic account of subjectivity, describing desire in terms of a temporally decentered subject. These are rich insights; however, as McIntosh (2015) has recently argued, these accounts tend to focus on specific theoretical or empirical aspects of temporality, or phenomena in linkage to it, rather than the theoretical form of temporality as such. McIntosh, for his part, calls for time as such to be treated as a discrete object of inquiry in IR, to which the field's existing

${ }^{5}$ Hutchings $(2008,7)$ casts theories of 'world-political time' as a broader category including 'theories of world history'. 
schools owe novel accounts. ${ }^{6}$ We focus on time on a large scale, linking IR to theoretical understanding of macro-history.

IR scholars who focus on hypothesis testing, model building, and statistical analysis may be understandably skeptical that a scientific discipline should concern itself with the problem of history. But even hypothesis testing invests tacitly in broad theoretical assumptions, to the extent that it addresses the relative historical consistency of actors and events over time. Hence, most or all major IR theories take implied stances on the problem of history. ${ }^{7}$ As many IR grand theories draw on historiography and political philosophy, they build in the historical-theoretic assumptions of their forbearers. IR theorists thus do not generate propositions about history ex nibilo. Instead, assumptions about history give rise to IR theories. We aim to show below that attention to theories or philosophies of history is both necessary and potentially productive for the discipline at large.

\section{Theories of history in the history of political thought}

Here, we briefly review core debates in philosophy of history. Doing so orients our analysis of IR scholarship below, and may provide guidance to IR scholars in assessing their own historical-theoretic commitments. ${ }^{8}$ The problem of history has a long pedigree in Western thought, although it developed in its present form, and in the sense meant by us, only in early modern political philosophy (Fortin 1979). At the core of modern philosophy of history is a transformation of humanity's relationship with nature. Early modern science and philosophy rejected the classical Greek and Christian worldviews, in which humanity was thought to exist within a cyclical natural order. Early modern philosophers such as Bacon and Hobbes instead argued humans and their societies stood apart, and

${ }^{6}$ This literature has grown rapidly. See Berenskoetter $(2011,648)$ on reflexive constructivists as 'students of the future', Lundborg (2012) on the event as a temporally laden concept, and Stockdale (2015) on 'anticipatory governance'. On time in sociology, see Abbott (2001).

${ }^{7}$ Assertions history is unimportant for given theories still imply a stance on history, indicating the theorist has circumscribed history and located his or her theory outside it. Doing so is in itself a historical-theoretic move, demarcating history in theory-laden ways. An anonymous reviewer offered a useful example: the Correlates of War IGO data set undercounts intergovernmental organization members by coding past international actors (non-sovereign statelets, principalities, etc.) according to a presentist conception of statehood.

${ }^{8}$ We emphasize 20th century continental thought. History has been less central in analytical philosophy, peaking in the 1960s (Glock 2008). For canonical accounts, see chapters in Dray (1966), especially by Donagan, Dray, Hempel, Mink, Passmore, and Walsh. While not analytical, the British philosopher of history Collingwood (1994) spoke to related debates, rejecting trajectory, regularity, and objectivity alike. Among 20th century Anglophone historians, Toynbee (1934) was almost alone in claiming grand historical trajectory. 
importantly over, nature. The separation of humanity from nature had political implications, making human community nonnatural, or socially constructed. It thus demanded explanation, and that explanation would necessarily be historical, tracking the emergence of the social order from the natural one. ${ }^{9}$

With history came the idea of progress, and the possibility of its absence. Although early modern articulations focused on the improvement of material conditions - the 'relief of man's estate' (Bacon 2001 [1605], 34) later work introduced other elements: the improvement of morals, sentiments, and culture. Nature, carved off from the social sphere, was understood (following Newton) as a discrete realm of unchanging necessity. This account of the human condition as historically, socially constructed took on central importance in the philosophies of Rousseau, Vico, and Kant. The approach reached its height in Hegel and Marx, for whom history decisively shaped humankind's political, spiritual, intellectual, and material conditions - a doctrine later termed 'historicism'. ${ }^{10}$

While universal histories in the style of Marx or Hegel gradually fell from favor, two debates they articulated remained influential: the question of whether history has a knowable, universal structure, and whether the important elements of that structure occupy a transformative trajectory or remain fundamentally the same. For some - many Enlightenment liberals, as well as Marx - this structure had a linear, demonstrable trajectory pointing into the future. For others, however - chiefly Hegel - history had a structure knowable only in retrospect, when some feature of it (e.g. freedom or reason) arrived at an absolute moment of decisive and complete articulation.

The emphasis on linear history had widespread appeal in the 19th century: it can be seen in the 'standard of civilization', which temporally marked out a path of social progress that demarcated civilized from not (Gong 1984; Keene 2014); and early articulations of social science - known best to IR from Carr's (2001a) and Waltz's (1959) criticisms - that made claims about the linear, transformative potential of history. The theory of history found in Comte's 'positivism', for example, saw the human sciences as securing humankind's progress (Löwith 1957, 67-91). ${ }^{11}$

${ }^{9}$ Hence the rise in importance of prehistorical states of 'nature'; on this see Manent (1994, esp. 23-24).

${ }^{10}$ Constraints of space preclude exploring further the complexity of historicism in political philosophy from Rousseau to present. For a brief synopsis, see Fortin (1979). On historicism in IR, see Roberts (2006).

${ }^{11}$ Its vestigial remains abound today in popular discourse - for example, in US President Obama's rhetoric of historical progress. 
By the 20th century, arguments for universal historical structures had been largely rejected, but the core historicist emphasis on transformation remained. While this turn had roots in by Rousseau's earlier critique of the Enlightenment, it was most influentially articulated by Nietzsche. In Nietzsche's $(1980,11)$ account of historicism, man cannot help but be aware of history's variability, and thus of the inscrutability of both past and future. Humans are part of history, shape it, and are aware they do so. But one location in history (the past) can be understood only subjectively from another (the present). It thus becomes difficult, or perhaps intellectually deadening - because it requires too high levels of abstraction from the needs of the present - to generalize across historical periods. From within the 'alpine valley' of historicism, where most humans live, however, one can neither see into neighboring valleys nor float above, taking in the transhistorical whole. ${ }^{12}$ Taken in this radical sense, historicism strips away even consistency of meaning over time, rendering the past unintelligible: 'only something which has no history can be defined' (Nietzsche 2003, 53). The impact of radical historicism in philosophy is difficult to exaggerate: it was taken to imply a challenge to the possibility of philosophy or knowledge as such. ${ }^{13}$

In Nietzsche's wake, approaches to the problem of history proliferated across 20th century scholarship. ${ }^{14}$ Many appeared as schools of textual interpretation, in the history of political thought. Disagreements about the shape and nature of history - its intelligibility and structure - shape disagreements about how much past thinkers are circumscribed by the contexts of their own time and the attendant problem, illuminated by Hegel and Nietzsche alike, of whether or not (and how) contemporary scholars are themselves free of such circumscription, and thus able to meaningfully reconstruct past ideas. ${ }^{15}$ Nonetheless, progressive ideas of history as

12 At least not without superhuman efforts or, in Nietzsche's (1980) own case, the 'untimely experiences' afforded to him by classical philology (8); c.f. also his criticisms of 'superhistorical men' (12-14).

13 See for example, Nietzsche (1967, preface), Heidegger (1962, 424-55), and Ricoeur (1965, 44-52).

14 See Husserl (1970), Gadamer (2000), Oakeshott (1999, 1-128), and Strauss (2013, 135-212). Note that Nietzsche $(1980,10-11)$ hedged bets: 'the unhistorical and the historical are equally necessary for the health of an individual, a people, and a culture .... We must then consider the capacity to perceive unhistorically to a certain degree as the more important and fundamental so far as it provides the foundation upon which alone something right, healthy, and great, something truly human may grow'.

15 See for example, the Cambridge School emphasis on historical linguistic context (Skinner 1969; Pocock 1971). In contrast, Straussians and others place the ideas and thinkers of multiple periods in dialogue with one another (Tarcov 1983; Beiner 2014). Foucauldians and other poststructuralists see the human subject as fundamentally historically constituted according embedded power structures (Foucault 1980, 78-133). 


\begin{tabular}{|l|l|l|}
\hline & Familiar & Unfamiliar \\
\hline Nonlinear & $\begin{array}{l}\text { History is largely static or } \\
\text { cyclical; familiar and } \\
\text { unchanging-e.g., realism, } \\
\text { hegemonic transition theories }\end{array}$ & $\begin{array}{l}\text { History is unpredictable and has no } \\
\text { grand internal logic-e.g., some } \\
\text { constructivism, poststructuralism, } \\
\text { much academic historiography. }\end{array}$ \\
\hline Linear & $\begin{array}{l}\text { History follows a certain path, } \\
\text { one familiar to the observer- } \\
\text { e.g., liberal idealism, } \\
\text { modernization theory, } \\
\text { neoliberalism, Marxism }\end{array}$ & $\begin{array}{l}\text { History has a unidirectional course } \\
\text { that is unfamiliar-e.g., }\end{array}$ \\
\hline Multilinear & $\begin{array}{l}\text { Hegelianism, some constructivism, } \\
\text { paths-e.g., English School } \\
\text { plurality of international orders, } \\
\text { or the multiple paths of uneven } \\
\text { development }\end{array}$ & $\begin{array}{l}\text { someries of globalization } \\
\text { paths. Past and future are } \\
\text { relative-e.g., postcolonialism, } \\
\text { other pluralist critical theories }\end{array}$ \\
\hline
\end{tabular}

Figure 1 Theories of history

knowable and improving, by various mechanisms, remained hugely influential in political practice - most obviously in liberalism and communism. ${ }^{16}$ Moreover, the increasingly global character of political thought made room for new, polyvalent approaches to history, many of them critically minded. Postcolonialists (Said 1979), for example, implied a world of multiple histories, but with sharp constraints on intelligibility between them, as colonizers profoundly misunderstood those they colonized. In contrast, the recent trend toward world or global history has fed accounts of multiple trajectories that are intelligible, providing a polyvalent grand sweep of the modern world. In short, beyond having or lacking linearity, history may be multilinear, wherein cross-cultural dialogue or exchange is possible at particular confluences or meeting points whereupon difference does present 'alpine valley' incommensurability. ${ }^{17}$

\section{International political theories of history: a typology}

We derive from these debates a typology of historical-theoretic approaches. These assumptions constitute wagers (Jackson 2011, 34-35). We categorize them on two axes, yielding a two-by-three table (Figure 1).

16 See for example, Woodrow Wilson (in MacMillan 2001, 495-96), Lenin (1987, 54-175, 265-70, 272-73, 281-85), Kropotkin (1995, 4-40, 235-59), and Dugin (2012, esp. 15-31, 71-100, 156-83). Some nonetheless take a more careful view, cautioning against intervention in social and political life. See, perhaps surprisingly, Fukuyama (1992, 276-84, 328-39), who distinguishes the historical from the post-historical worlds, and is skeptical of post-historical liberal world-making.

${ }^{17}$ Philosophy of history remains a lively area, exemplified by recent output in two journals, Theory and History and the Journal of the Philosophy of History. 
First, theories of history may assert that the future is familiar based on the past, or that it is not. Second, theories of history may assert that the movement of history is linear, nonlinear, or multilinear.

The question of familiarity divides theories according to whether or not the problem of history alienates current researchers from the past. Theories may view the past as a basis for predicting the future, or may not. A theory in which this mediation is minimal or surmountable allows us to draw on the past to understand the future. Based on the past, the future will look intelligible because familiar. ${ }^{18}$ Alternately, history may offer no such grounds, leaving the observer isolated in a given moment in history, trapped in a Nietzschean alpine valley: the past looks strange, and the future obscure. Familiarity of the future is not knowledge of it - it implies intelligibility, not any specific prediction. Realism and liberalism, for example, both identify futures recognizable to the observer, but not particular events they will comprise. Scholars may also reduce the scope of intelligible historical fact in order to predict the future - as we argue with neorealism. For these reasons, we term this axis 'familiarity' instead of its related correlate, knowability.

The second question divides theories according to whether or not, and how, the past has a linear trajectory. Linearity refers to a long-run direction of transformative movement: a pattern of historical change to which we can attribute either a teleological destination or ongoing development in a definable direction. ${ }^{19}$ It refers then not just to change, but to change with an intelligible form - a past that has yielded to present, and possibly will to future, in a way exhibiting a pattern that does not simply repeat. Liberals, Marxists, and others, assert linearity. Such theories may project a teleological or eschatological final destination, or not, projecting continuous, asymptotic movement - as does Kant's. Linearity may be a property of dialectic: localized oscillation may have directionality at scale. Theories may have one of three ideal-type linearities: none, a unified direction, or a multilinear plurality of actual or potential trajectories. ${ }^{20}$ Importantly, the ability of researchers to advocate for linearity or nonlinearity hinges on the knowability of historical fact, making the relationship between knowability and linearity important. If history is linear but unfamiliar, linear narratives can only be constructed concerning the past. More familiar history permits clearer projection of linearity into

${ }^{18}$ For a review of barriers to prediction in IR, see Jervis (1991, 39-46).

19 We thus do not intend analogy to a linear statistical relationship. A flat linear statistical relationship would not be linear in our sense, but an exponential one would.

${ }^{20}$ We would like to thank an anonymous reviewer for suggesting distinct attention to multilinear accounts. 
the future, or clearer knowledge that history is nonlinear or multilinear. These two distinctions yield six types of theory of history, distinguishable on a two-by-three table (Figure 1).

The top-left cell captures theories that view history as familiar, but nonetheless nonlinear. On such accounts, history has no destination or linear trajectory. Indeed, it is a lack of change, or the knowability of transhistorical causes of events, that permits predictability, since the future resembles the past. ${ }^{21}$ Such accounts include most kinds of realism and cognate schools, such as power transition theory. The middle-left cell captures theories that view history as linear and familiar. Here, history has an identifiable trajectory, making events linearly familiar, and prediction possible. Such theories include liberal narratives, according to which history has a general trend, colloquially termed 'progress'. ${ }^{22}$ In the bottomleft cell, history may be knowably linear, but multiply so, following more than one intelligible trajectory. Here we find later, more pluralist English School research, as well as theories of uneven development.

The top-right cell captures quite different theories, according to which history is neither familiar nor knowably linear. Prediction is impossible: myriad localized contingencies determine history's shape. In IR, many constructivists and postmodernists see history as socially, culturally, or linguistically contingent. Such accounts assume theoretically a long-term lack of both historical structure and familiarity. The middle-right cell captures theories that view history as unfamiliar, but linear. Here, the future is unpredictable precisely because it will differ from the past. History is a linear process of transformation that reveals its logic only as it occurs. The trajectory of history is visible in the past, but not in the future. The founder and most famous exponent of this last view was Hegel, and many of his intellectual descendants tacitly or explicitly share it, including a minority of constructivists. A final cell, at bottom right, captures theories that are similarly linear and unfamiliar, but plurally so: here, multiple trajectories of change proliferate each limited to its own subjectivity. Such is the case with some critical, postcolonial, or intersectional understandings of world politics.

21 This does not entail absolutely no change - empires rise and fall, religions come and go, etc. Nonetheless, fundamental underlying processes, such as human nature, remain unchanging.

22 Differences between linearity and cyclicality are often matters of scale. A small crosssection of a cycle looks linear, while a recurring cycle may at macro level comprise an overall linear trajectory (Toynbee 1934). Nonetheless, theorists generally emphasize a specific times cale. Realists may admit an alternative to anarchy once existed, and could again, but make no theoretical claims about them. We emphasize the timescales theorists do. On related matters, see Gould (1987) and Jervis (1991, 44-45). 
The two axes can be understood very roughly as corresponding to ontologies and epistemologies of history, but are not coeval with them. The question of familiarity addresses knowability, suggesting that familiarity derives from an epistemology of history: whether it can be known, or not. Indeed, the philosophy of history as a distinct project arose largely within the ambit of epistemological questions. Knowability is not confined to epistemology, however, nor is it exhaustive of epistemological questions. For example, history may be unfamiliar because it is too complex, historical 'data' thus unorderable into a familiar pattern. In this instance, complexity, not the narrowness of one's view, makes history unintelligible. These constraints have consequences for scholarship: some IR treatments of history reduce the scope of historical facts deemed relevant, or treat facts as transhistorically 'objective', eliding context dependence. ${ }^{23}$ In contrast, although linearity implies a claim about the ontology or ontics of history what things a given theory aims to capture and make intelligible - how these are related to epistemology can differ from theory to theory. For example, Kant's (1991) theory of history proposes historical linearity without consequently affirming that progress exists independently of the knower, 'out there' in history. Neorealist IR theory, we show below, generates nonlinearity only by excluding from analysis history not concerned with the international system.

Like any ideal-type or analytical image, these two axes therefore cut with a blunt edge. ${ }^{24}$ More specific questions of ontology and epistemology are 'cashed out' only the individual cells. Unfamiliarity as an epistemic property may interact differently with linearity depending on a theory's ontology of history. Nonlinear unfamiliarity, for example, implies postmodern skepticism about long historical trajectories. Linear unfamiliarity implies a known past, but as-yet-unthinkable future. The shape of history thus informs how intelligibility and nonintelligibility plays out in practice. Inversely, familiarity and unfamiliarity yield differing nonlinearities, generating ontological differences between poststructural approaches (unfamiliar and nonlinear) and realisms (familiar and nonlinear).

Some thinkers we cite - for example, Marx and Herodotus - fit less neatly than others. We can locate them in the table only with considerable simplification of their complex views. Doing so nonetheless serves an important purpose. In Jackson's words, 'instead of a representation or a depiction, it is a deliberate over-simplification of a complex empirical

${ }^{23}$ We thank the editors of International Theory and the reviewers for pressing us on this distinction.

${ }^{24}$ On this score, see Healy (forthcoming). 
actuality for the purpose of highlighting certain themes or aspects that are never as clear in the actual world as they are in the ideal-typical depiction of it' $(2011,37)$. Our point is not that IR theories can be neatly delineated into categorical boxes, but that doing so reveals what would otherwise be obscured. Our typology serves to better order the assumptions made by most (but not all) IR theories about the history of international politics. ${ }^{25}$

Beyond this, its purpose is analytical, telling us things we might not otherwise know. Below, we find unexpected internal disagreements within IR-theoretic schools about the nature of history. Most realists fall roughly in one box, but some (especially Carr) are exceptional. Divergent constructivisms appear in multiple boxes, giving voice to multiple understanding of how history works, and how it can be known. Critical IR, always a diverse school, implies internal disagreements about both the trajectory and knowability of history. Our purpose is not neat categorization, so much as an intervention in ongoing misunderstanding between and within theoretical approaches. The two sections below develop these types in greater detail.

\section{Theories of history as familiar}

\section{Nonlinear and Familiar}

In IR, the main advocates of historical stasis or cyclicality are realist. Modern political realism, in both its classical and neovariants, insists transhistorical forces (human nature or structural pressures) impose persistent trends on history. In so doing, realists claim descent from specific classical and early modern theorists. They note Thucydides called his insights on the Peloponnesian war a 'possession for all time': ${ }^{26}$

[I]f they are judged useful by any who wish to look at the plain truth about both past events and those that at some future time, in accordance with human nature, will recur in similar or comparable ways, that will suffice. It is a possession for all time, not a competition piece to be heard for the moment, that has been composed (1998, 13-14).

${ }^{25}$ Linearity and familiarity do not exhaust possible distinctions: others may be drawn as well. For an expansive survey of possible dimensions, see Vašíček (2009, 29-30).

${ }^{26}$ Gilpin (1983, 199-207, 211, 227-28) and Morgenthau (1946, 42); see also Hobbes (1989, xxi) on Thucydides: 'For the principal and proper work of history being to instruct and enable men, by the knowledge of actions past, to bear themselves prudently in the present and providently toward the future'. 
Even Machiavelli, who helped found modern conceptions of progress by dismantling the more constrained Ancient view of political change, is read similarly. Realists may cite Machiavelli's references to the ancients:

Whoever considers present and ancient things easily knows that in all cities and in all peoples there are the same desires and the same humors, and there always have been. So it is an easy thing, for whoever examines past things diligently, to foresee future things in any republic and to take the remedies for them that were used by the ancients, or, if they do not find any that were used, to think up new ones through the similarity of the ancients (2009, 83-84).

Realists find in such claims an ahistorical stratum to world politics: the problems that confronted Thucydides are also those confronting modern scholars and policymakers. They thus repeat - in balances of power, rising and falling hegemons, and the like. ${ }^{27}$ Waltz expressed much the same ahistoricality:

International politics is sometimes described as the realm of accident and upheaval, of rapid and unpredictable change. Although changes abound, continuities are as impressive, or more so ... The texture of international politics remains highly constant, patterns recur, and events repeat themselves endlessly. The relations that prevail internationally seldom shift rapidly in type or in quality. They are marked instead by dismaying persistence[.] (1979, 65-66).

The view is readily found in Mearsheimer $(2003,2)$ and Gilpin $(1983,211)$.

However, realist claims to intellectual descent from these theorists are not wholly accurate. For example, Machiavelli also offered a new, modern account of humanity as master of nature and maker of its own history (Walker 1993, 104-24; Mansfield 1996, 109-22; Pangle and Ahrensdorf 1999, 123-44). A cyclical reading of Machiavelli is a reconstruction (arguably distortive) by modern realists. Thucydides' subscription to a cyclical theory of history is disputed (e.g. Hornblower 1991, 61). ${ }^{28}$ Why then is this cyclicality so central to realist readings of these canonical texts?

Our answer is that modern political realism began largely as a project of interrogating linear, progressive understandings of history that dominated statesmanship in the late 19 th and early 20 th centuries. Twentieth century

27 To achieve this view of history, international factors - balances, hegemonic wars, etc. - are distinguished from domestic-level changes ('history' conventionally understood); the former are emphasized.

${ }^{28}$ See also the general correctives of Welch (2003) and Pangle and Ahrensdorf (1999, 13-32). 
'classical' realists recognized that history shaped domestic politics, but saw other elements of political life - thought to stem from nature - as transhistorical. These elements varied: for Niebuhr $(2008,17-23)$ this was the cupidity stemming from original sin; for Morgenthau $(1948,13)$, man's 'animus dominandi', to seek 'control over the minds and actions of other men'. Neglected by historicists, these elements made history conflict-prone and curtailed hopes for permanent political change. ${ }^{29}$ Liberal institutionalizing or communist revolutionary efforts at historical transformation, even if genuine or politically unopposed, will be impeded by the permanencies of history (e.g. Niebuhr 2008, 140-43). Thus, at its inception, IR theory had an explicit stake in historical understanding - one that falls from view in textbook presentations of realism, emphasizing its state-centric ontology and generic 'pessimism', simplifying and obscuring historical sensitivity (Mingst and Arreguín-Toft 1999, 63-68; Baylis, Smith, and Owens 2010, 4, 86-91; Sens and Stoett 2002, 13-18)..$^{30}$

Although neorealism offers no explicit account of history, it implicitly expanded upon classical realism to generate a systematically cyclical view. Ironically, the success of realism's transhistoricism may have contributed to the field's move away from history and toward an emphasis on generalizable covering laws: in seeing politics as unchanging, realists could apply their account across historical contexts. From there, a turn to ahistorical scientific theory was straightforward. No single account better embodies this than Waltz's $(1979,65-66)$ elegant recasting of realism, which presents historical continuity as a consequence of realism's foundational assumptions, rather than an assumption. Waltz is most commonly summarized as moving from the ordering principle of anarchy, and the distribution of power across units, to self-help, a security dilemma, a structure (uni-, bi-, or multi-polar), and a balance of power. War and peace in the international system result from imbalance and balance, respectively. The system will trend toward equilibrium, as units vie to prevent one another dominating (Waltz 1979, 121, 209).

Missing from this recitation are the temporal assumptions of Waltzian theory. ${ }^{31}$ Waltz assumes static units with fixed preferences. These units are

29 Thus while realist rejoinders to liberalism were solicited by the particular concerns of the time, they were not historicist per se.

${ }^{30}$ Classical realists were not unified in their view of history. Exceptionally, we show below, Carr held linear-unfamiliar views; compare with Niebuhr's (2008, 1-16, 65-88) complex view of progress in history, and Kennan's (2012, xlv-lii, 102-09, 113-34) various statements. Although Morgenthau $(2004,15-16)$ later advocated the establishment of a world state, his view that politics contained important transhistorical elements lasted throughout his career. See discussion in Williams (2005).

31 Theory only - Waltz $(1979,91-92)$ allows that practice may diverge in multiple ways. 
alike - functionally undifferentiated and prone to one persistent interest over time: survival (Waltz 1979, 79-82, 88-101). He then depicts resulting structures in equally static ways, offering fixed images, rather than dynamic processes. The only movements driven by systemic pressures are a repeating return toward balance, and occasional changes in the number of great powers, yielding new polarities (Waltz 1979, 102-28, 199-210). Having assumed static units, under a static organizing principle, depicted in static theoretical images, Waltz does not demonstrate recurring patterns - he assumes them. Since these assumptions cover long-term trends in world politics, they draw on a general theory of history as such. ${ }^{32}$ Neorealism thus 'black boxed' realism's view of history, concealing it behind its own theoretical consequences. Early critics of Waltz's inability to explain historical change (Ashley 1986; Ruggie 1986; Walker 1993) tacitly glossed over the very critique of historical progress that had given realism its foundations. We find an analogous pattern in the history of liberalism. ${ }^{33}$

\section{Linear and familiar}

Perhaps no IR-theoretic school has been more associated with a narrative of progress than interwar liberal idealism. Carr thus quoted Woodrow Wilson on the historical necessity of the League of Nations: 'If it won't work, it must be made to work' (2001a, 8). Carr saw in this an obstinate refusal to separate facts from values. However, Wilson also implied a view of history: that it follows a fixed and identifiable trajectory toward concrete instantiation of liberal-democratic systems of rights, as transhistorically just. Wilson's belief in the League's necessary success demonstrated not only the magical thinking Carr diagnosed, but also a belief that history followed a very real progressive line. This same assumption can be found at work in Wilson's Fourteen Points: trends toward national selfdetermination, more and freer trade, greater international legal openness and formality, and robust international institutions, all reflect not only principles, but a historical trajectory toward greater instantiation of Wilson's own progressive values (MacMillan 2001, 495-96). He believed he could seek and expect these outcomes because history was on his side.

Early liberal IR theorists thought much the same. Angell (1972, 59-60) claimed that the realist association of political power with national

32 Power transition theories (Modelski 1978; Gilpin 1983) replace stasis with cycles, but still depict history as nonlinear and familiar - the cycles themselves recur. See discussion in Adler (1991, 45-46).

${ }^{33}$ Waltz $(1997,914-15)$ claimed to reject prediction, but nonetheless made general claims about the future, endorsing theory that 'predicts strong and persistent tendencies'. On Waltz's approach to theory, see Waever (2009) and Jackson (2011, 112-52). 
greatness 'belongs to a stage of development out of which we have passed... $[\mathrm{W}]$ ar, even when victorious, can no longer achieve those aims for which people strive'. He drew on liberal economic theory, but also on a liberal narrative of progress: an account of history that moved linearly through stages, with war supplanted by peace and economic interdependence. On this account, the past was intellectually available to the observer, and the future predictable based on it. These ideas had roots not in classical political thought, but in Enlightenment thinkers, especially Locke and Kant. Enlightenment narratives of historical progress rely on a reshaping of scientific method and philosophy aimed at social improvement. For example, Kant's exhortations to progress and peace in world politics were predicated upon enlightened self-interest in service of a knowable, ahistorically just ideal. ${ }^{34}$

Neoliberal institutionalists implicitly replace this overt narrative of progress with an assortment of iterated games and developing or evolving institutions. In so doing, they reframed liberal linear development in the language of neorealist anarchy and rational-choice incentive structures. They thus revived progress by locating it contextually: international institutions, for instance, can be understood as progressing toward more and better attainment of their founding goals, in turn linked to convergent state interests (Axelrod 1984; Keohane 1984). Keohane, for example, concludes that 'Improvements (as judged by cosmopolitan moral standards) are more likely to be incremental than sudden, building on the knowledge of one another created by successful cooperation' $(1984,257) .{ }^{35}$ Such arguments elide teleology by employing evolutionary frameworks. They nonetheless assume states have similar interests across iterations, processes, and linear changes: chief among them, self-preservation. This concern extends to states' preference for outcomes in which gains are achieved through peace rather than through war.

Liberals are not alone in this category - some constructivists emphasize liberal patterns of normative development. ${ }^{36}$ Wendt, in his influential constructivist account of cultures of anarchy, takes a particularly explicit

${ }^{34}$ Kant's influence on IR liberalism is extensive. See for example, Doyle (1983).

${ }^{35}$ Keohane is careful to overtly separate facts from values, but nonetheless returns repeatedly to the moral consequences of his argument.

36 Some liberals (Deutsch 1966) later referenced by constructivists also fall in this category. Some constructivists approach this category but are not systemically within it. Accounts of cascading human rights norms or the transformative activist networks track a self-reinforcing trajectory toward greater rights and liberty (Keck 1998; Risse, Ropp, and Sikkink 1999). That trajectory is nonetheless localized to late modern liberal world order, and requires human action to instigate. 
line, arguing incentives inherent in world politics privilege moving from a costly, violent culture of anarchy to a peaceful one. There is 'no historical necessity' to this movement, but neither is a lack of progress necessary: 'The passage of time may simply deepen bad norms, not create good ones. Note that this is different from saying, as Realists are wont to do, that progress in international politics is impossible' (Wendt 1999, 311). Progress nonetheless represents the most likely future: 'the history of international politics will be unidirectional: if there are any structural changes, they will be historically progressive' (Wendt 1999,312 ). ${ }^{37}$ Put differently, Wendt assumes that states will prefer pacific international environments to bellicose ones because of the costs associated with the latter. Although Wendtian world political progress is uncertain, history is not circular or static; rather, a linear historical ordering principle most likely underpins world politics at any moment. Movement along this linear trajectory is likely, but not definite. Wendt's (2003) presentation in Social Theory partially anticipates his more forceful pronouncements about world statism. ${ }^{38}$

While liberal ideas remain tied to narratives of progress, Marxism works differently, describing an oscillating trajectory of dialectical contention that is linear only over the long haul. ${ }^{39}$ Thus the Communist Manifesto begins with the assumption that 'The history of all hitherto existing society is the history of class struggles' (Marx and Engels 1992, 3). Linearity is made possible by an underlying constant: 'the exploitation of one part of society by the other' (Marx and Engels 1992, 25). History follows a familiar path, generated by recurring processes of conflict between economic classes, culminating in revolution. ${ }^{40}$ However, the familiarity of the future has one exception in the Marxist account: Marx and Engels (1992, 25-26) predicted a terminus in revolution, but specified little about the politics to follow, since the underlying condition driving history and making it knowable (class exploitation and conflict) would have ended. Beyond this point, history as such ceases. Marxism nonetheless parallels liberalism in its observation that history has a knowable trajectory. Later formulations, such as Lenin's, emphasize human intervention to bring society closer to that end-point. Broadly historical-materialist IR-theoretic schools of thought have tended to replicate this dialectical historical determinism.

37 See also Wendt (1992, 417-21).

38 As Wendt's views have become more overtly teleological, he increasingly stands apart from most mainstream constructivists, who tend to locate progress at a lower level. See Footnote 36.

39 What is dialectical at the local level may be linear in aggregation. See Footnote 22: time scale matters. Some scholars informed by Marxism emphasize multilinearity. See discussion of Rosenberg in the next section.

40 See for example, Wallerstein (1979) and Cox (1986). 


\section{Multilinear and familiar}

A third class of theories view history as familiar - that is, comprehensible, past and future - but as having no single, unified course. Such theories view history as multilinear, in the sense of having more than one discrete trajectory. The form of human history remains traceable, but once viewed from above the rim of the alpine valley, it moves at no one tempo, and in no single direction. History is knowably, documentably heterogeneous, reaching as a whole no specified terminus nor exhibiting a single set of unfolding, transhistorical ideas. On such views, the future is intelligible, but not predictable. Because it may follow more than one course, no one possible state of it looks certain from the present. We can observe, reason, or speculate usefully about potential states of the world, just as we may make sense of how past trajectories of human experience have differed across individuals and communities experiencing it. However, we cannot say where specific individuals or communities are headed. Indeed, they may be headed in different directions.

Such accounts are increasingly common among global or world historians who criticize earlier convergence narratives. For example, attempts to account for the so-called 'great divergence', during which the Euro-Atlantic area broke away from the rest of the world economically and power politically, almost necessarily require attention to divergent historical courses (Pomeranz 2009). Osterhammel's (2014) history of the long 19th century finds an abundance of transformative events and processes, firing in multiple directions. These accounts feed into Buzan and Lawson's (2015) recent account of the 19th century as a polyvalent 'global transformation'. Buzan and Lawson also draw on Rosenberg's (2006) conception (in turn from Trotsky) of 'uneven and combined development', whereby the existence of an international system results in part from uneven economic development globally. Unevenness becomes a precondition for the combined development of the system itself. ${ }^{41}$

In contrast to this economic emphasis, some multilinear IR-theoretic approaches focus on varieties of international order. Acharya's (2014) call for a 'global IR' is indicative. Here we have the opposite of convergence the field is confronted by divergent, co-existing futures. Similarly, we might view Katzenstein's (2009) plurality of civilizations as a culturally multilinear constructivism. Accounts of a fundamentally different historical structure in premodern East Asia offer global-historical multilinearities (Hui 2005; Kang 2010). Interactions between such diverse international structures may be generative of differing regional identities (MacKay 2016).

${ }^{41}$ Abbott's (2001) sociological rejection of 'general linear reality' belongs here as well. 
Later, more pluralist formulations of the English School, especially those of 'regional international societies' offered another such approach (Buzan 2014, $57-59,180-81) .{ }^{42}$ Philips and Sharman (2015) offer an account of 'durable diversity' of actor type within international orders - referring empirically to the early modern Indian Ocean littoral. Durable diversity within systems implies such orders may also differ from one another - as with the early modern European order they imply as a contrasting case. By extension, history can and perhaps must contain multiple trajectories, and may indeed be understood as constructed - as assembled by the theorist or observer from historical facts.

Still, familiar multilinearity remains a minority view in IR, perhaps because of the field's bias toward historical convergence (Phillips and Sharman 2015, 23, 29), wherein international order converges on a single configuration (often liberal), dominated by one kind of actor (the sovereign, territorially exclusive state). Rosenberg imagines multiple trajectories chiefly to explain the existence of a unified larger one. Importantly, these accounts are themselves diverse, imagining different international orders and historical trajectories. However, they have in common histories that move in no one direction: we can know history, but not reduce it to a single unifying narrative.

\section{Theories of history as unfamiliar}

\section{Nonlinear and unfamiliar}

A fourth category captures theories that reject both explicit linearity and an intelligible future. Many social scientists may regard themselves as belonging here, but be surprised to find their theoretical commitments categorized elsewhere. True skepticism about both historical trajectory and intelligibility is rare, requiring a deep commitment to historical specificity. Here, history so decisively shapes humankind's intellectual conditions that it constrains knowledge outside the immediate present. Prediction as such is likely impossible, as is the ability to know whether history has any overarching structure. ${ }^{43}$ Among political theorists, it is often found in the

${ }^{42}$ However, the classical realist/rationalist/revolutionist formulation of the English School (Wight 1992; Buzan 2004) described no co-existing plurality of trajectories, only multiple possible lines. Wight imagined a single international order, toward which regions of the world converged (Wight 1977). However, see Butterfield's (1965) critique of 'Whiggish' views of history. Alternately, English School approaches may begin outside the European international order, and still non-European societies' track convergence with it, as does Suzuki (2009).

${ }^{43}$ Indeed, these theories are usually taken to deny any trajectory, since history itself, a human creation, does not exist outside epistemologically constrained, historically constituted humanity. 
intellectual descendants of Nietzsche (Foucault 1980). Common to these approaches is the claim that knowledge of society must always begin with knowledge of place in history, sometimes called 'historicity' (Voegelin 1987, 1-20). This perspectivalism alienates the present from any knowledge that is not historically located. This undermines any systematic account of history as static or cyclical, since it locates historical social order not in fixed, universal patterns, but instead in historically local particularity. On this account, claims about liberal progress, for example, are not true for all time. They are instead reflections of the prevailing contextually specific knowledges of a given time and place.

As social scientists, however, IR scholars have generally looked for regularities - patterns recurring or unfolding over time. Most IR scholarship thus rejects this theory type's commitment to particularism. Still, some, but not all, scholarship in two broad categories falls into this group: constructivism and critical IR. While constructivists are a diverse group, many believe norms, beliefs, ideas, or identities can shape international political outcomes (Checkel 1998). From this flows perhaps the most basic and general claim in the constructivist repertoire, that 'anarchy is what states make of it': in effect, a generalization about the fact of specificity. ${ }^{44}$ This insistence on 'a world of our making' (Onuf 1989, 1-27, 35-43), and thus on necessarily localized history, distinguishes such constructivists from their more liberal peers surveyed above. ${ }^{45}$ While such constructivist claims are often more systematic than those of poststructuralists, their claims are relatively difficult to generalize in a predictive way. For these scholars, the intelligible past is constructed: the facts constituting it are necessarily selective (Reus-Smit 2008, 401-05). ${ }^{46}$

Critical and postmodern IR scholars almost uniquely recognize both the problem of history and the extent of its implications. ${ }^{47}$ In so doing, they often privilege critical narratives of history over conventional ones.

These theorists may reject prediction not as impossible, but as normatively objectionable - as with narrow, neoliberalizing narratives of progress. They would thus reject the positivist agenda in which they see prediction as a precursor to technocratic progress.

${ }^{44}$ Wendt (1992) nonetheless thinks history trends toward liberality - see above.

45 Similarly, Kratochwil (2006) theorizes change while implying no particular narrative of progress or universality.

${ }^{46}$ Reus-Smit $(2008,414)$ attributes this particular view to all constructivists. While we agree this core group adheres to it, we find many in other categories as well. Indeed, his account seems to describe constructivists in more than one box, as when he sees in constructivism a theory that 'denies that a singular history of international relations is possible', suggesting multilinearity.

${ }^{47}$ See for example, Walker's (1993, 6-25, 88-124) criticism of realism, which historicizes its claims to transhistorical truth by linking realism to the particularities of Early Modern political philosophy. 
Following the French poststructuralists (Lyotard 1984, xxiv), many critical IR theorists reject both grand narratives of progress, and objective knowledge of historical events. This gives rise to now-canonical critiques of neorealism and cognate theories (Ashley 1986; Der Derian and Shapiro 1989; Walker 1993). Their methods supplant descriptive objectivity with contending subjectivities or discourses (Hansen 2006). While it need not obscure all knowledge of the future, rejection of metanarratives implies rejection of the systematic accounts social scientists traditionally seek. ${ }^{48}$

Theories of this type are self-silent on history's 'true' trajectory: they view 'progress' as neither impossible nor inevitable. Instead, they question the very idea of a narrative of progress, which must be framed in terms of a given context. History is a construct, perspectivally arrived at, rather than a documentary account. Progress would depend conceptually on grand theories of history. It is those theories generally thought to be less scientific in orientation (poststructuralism and its cognates) that most selfconsciously fall into this category.

\section{Linear and unfamiliar}

Theories in the fifth category posit that history follows a line, but one that cannot be known in advance. Such accounts separate history's linear character from knowledge of it. On this view, we know history has a definite direction, but not what that direction is. The founding and most systematic proponent of this view is Hegel $(1988,2003)$, who claimed that philosophy (and by extension social science) could understand only the past, and not the future. History's linear trajectory is directed away from the known past and present, toward something necessarily different and unfamiliar. Its arc is visible only in retrospect: the lessons of the past will necessarily be inapplicable to the present and the future. Each historical epoch becomes philosophically meaningful only at its end - thus Hegel's famous assertion that 'the owl of Minerva spreads its wings only with the falling of the dusk' $(1967,13) .{ }^{49}$

Hegel's words are often taken as a general invocation against prediction in social science. However, they convey something more robust and specific, indicating not that history has no general trend - Hegel's theory of historical process is well known - but instead that the shape of that trend is knowable only to observers of the past. They thus describe not the

\footnotetext{
48 Admittedly a diverse lot, not all poststructuralists will recognize themselves in this account. Indeed, some such approaches may simply be incommensurable with the framework we employ.

49 We emphasize Hegel's theory of history. On his substantive reasoning regarding world politics, see MacKay and Levin (2015b).
} 
particularism of nonlinear, unfamiliar history, but instead something quite different. In IR, relatively few scholars offer linear narratives without specifying where they lead. Social scientific empiricism makes it difficult to declare trajectories both real and unknowable.

However, some IR theorists do make such claims. Perhaps surprisingly, Carr is among them. Carr's (2001a, 10) most famous realist work occasionally mentioned cyclical power-political patterns. However, Carr (1945, 38-70) elsewhere described the modern nation state emerging through successive stages of development, describing a linear pattern of development. He represented the future of that trajectory as unknowlable, subject only to speculation (something he was nonetheless quite willing to provide). Later, he described history as such in similar terms, endorsing a view of the future wherein progress is directed toward objectives we cannot yet specify. Carr $(2001 b, 113)$ thus asserted 'the possibility of ... progress subject to no limits that we can or need envisage - toward goals which can be defined only as we advance towards them, and the validity of which can be verified only in a process of attaining them'. This is Carr at his most Hegelian, articulating a linearity that nonetheless denied familiarity in advance. ${ }^{50}$

A minority of constructivists and their precursors also fall broadly into this category. Haas defined organizational learning (as opposed to adaptation), in terms of change toward goals yet to be established. Thus, learning (progress) becomes possible only when goals are self-consciously reassessed and revised. Thus:

One can think of human progress ... as an open ended groping for self-improvement, without a final goal, without a transcendent faith, but with frequent reversals and sporadic self-questioning about the trajectory of change ... Progress manifests itself more directly and forcefully when such collectivities pause to think about what they do, when they consider doing things differently in the future (Haas 1991, 212; see also Haas 1997, 5-12).

Adler (1991, 54-60) has framed things similarly, noting that, since progress requires self-examination, revised values, and revised intersubjective understandings, 'cognitive evolution' differs from biological evolution in being much more complex and much less predictable. In human history, psychological or cultural mechanisms of selection supplant natural ones. Progress is nonetheless possible - it merely moves toward goals by application of means that are both established along the way. The innovation, selection, and diffusion of ideas interact to produce objectives

${ }^{50}$ Carr's philosophy of history was deeply informed by Collingwood (1994). He was nonetheless a theoretical pluralist - his broader debts were to Mannheim. 
and outcomes alike that are unpredictable, but nonetheless constitute progress of a meaningful kind, the destination of which is defined by the same evolutionary processes. ${ }^{51}$

Few IR theorists belong in this category perhaps because it represents in some respects the most ambitious form of historical-theoretic thought, and the distinctive province of the theorist most associated with philosophy of history - Hegel.

\section{Multilinear and unfamiliar}

In a final category, history has multiple trajectories, but for precisely this reason is obscure to the observer. This is radical pluralism about historical directionality, whereby divergence of paths makes reliable knowledge of more than one difficult, or perhaps impossible. ${ }^{52}$ Such accounts are related to, but distinct from, nonlinear-unfamiliar views. Instead of negating all linearity and knowability, accounts in this category see historical trajectories proliferating, but largely invisible to one another. They are defined internally, invoking conceptions of their own pasts and value systems that are largely or wholly obscured from one another.

Thus, the unknowable nonlinearity of poststructuralism is supplanted by a plurality of trajectories, largely unintelligible to one another. Here we find some of the most innovative critical scholarship in recent IR. Barkawi and Laffey (2006) call for a postcolonial security studies that sees the world from outside the Eurocentrism of conventional accounts. Inayatullah and Blaney's (2003) account of the 'problem of difference' speaks to the field's apparent inability to address the developing non-West. They trace this blindness to IR's emergence as an intellectual project at the height of European imperialism. More broadly though, this is the old and thorny philosophical problem of the self and the other: of giving voice to alterity. When, two decades ago, Tickner (1997) proclaimed to the field writ large that 'you just don't understand' the concerns of feminist IR theory, she pointed not just to substantive differences in subject matter, but to differences in ontology, epistemology, and purpose of IR scholarship. Such concerns reflect deep differences in the historical trajectories of the groups whose experiences they take up. ${ }^{53}$

51 This arrangement is nondeterministic, because such evolutionary paths are likely but not inevitable: the indeterminate character of cognition makes strict determination of the world political future impossible.

52 The recent 'ethnographic turn' in IR (Vrasti 2008; MacKay and Levin 2015a) is located here as well.

${ }^{53}$ Hutchings (2007) thus refers to the 'heterotemporality' of postcolonial and critical feminist IRs. 
These views are necessarily plural, but also not wholly knowable to one another, as the problem of difference, of alterity, entails. They are thus linked to recent calls for increased intersectionality in the field (Ackerly and True 2008). They reflect proliferating and potentially overlapping views, from any one of which world politics must be experienced and assessed anew. Nonetheless, their specificity of perspective should not be mistaken for specificity of subject matter. Thus, for example, when Sjoberg (2012) offers a feminist reformulation of Waltz (1979), the purpose is to recapture a general view of international politics 'through feminist lenses'. ${ }^{54}$

While these examples are recent, their postmodern linkages may also have premodern, indeed ancient connotations. The category finds implicit premodern roots in histories that emphasize cultural difference and exchange. The Ancient Greek historian Herodotus perhaps represents the best Western example. His 'Histories' - the Ancient Greek istoriai, which means 'inquiries' - is far from a conventional 'history'. ${ }^{55}$ Converging on the Persian invasions of Greece, Herodotus' vast account examines how different customs and traditions (nomoi), even when drawing from one another, shape different collective understandings of decisive historical events, creating great differences in historical narrative between the peoples he examines. ${ }^{56}$ Importantly, the figures and cultures that populate the narrative often lack understanding across these cultural chasms, ${ }^{57}$ with the notable exception (by inference) of the author himself. ${ }^{58}$

Such differences of experience may give rise to differences of aspiration, and varied conceptions of flourishing - that is, differing objectives. This is pluralism not just of experience, but also trajectory, both real and aspirational. A plurality of viewpoints elides easy summary - we aim here lie here.

${ }^{54}$ Recent pluralist, left-anti-liberal appropriations of Schmitt (Odysseos and Petito 2007) also

55 Benardete notes Herodotus's 'inquiries partly result in the presentation of events that are now called "historical"; but other parts of his inquiry would now belong to the province of the anthropologist or geographer' $(1999,7)$. The link between critical IR and Herodotus is not without precedent. On Herodotus's untapped IR-theoretic potential IR, see the brief note in Walker $(1993,66)$.

56 Virtually the entire work is taken up with presentations of narratives and customs, but see especially Book 3.38; compare with the exhortation to empire in Book 7.8 (Herodotus 2010, $228,469)$.

57 See for example, Book 7.101-105 (Herodotus 2010, 502-04).

${ }^{58}$ Herodotus' inquiries require an observer able to understand each custom as it presents itself - as a claim about human flourishing - while fruitfully comparing it with others. These inquiries thus aim to partially transcend the hermeneutic barriers of convention for the purposes of genuine comparison, but while accepting neither an 'objective' viewpoint that would remain too 'external' to each culture, nor a perspectival relativism that would preclude genuine comparison. 
only to indicate their scope and range of intentions. Accounts in this category also almost necessarily understand the past as constructed: as recollection understood differently through differing lived experience. They are also most likely, alongside nonlinear-unknowable accounts, to directly interrogate the problem of history, and to doubt parsimonious solutions. ${ }^{59}$

\section{Conclusion}

This article has aimed to systematically document philosophy of history at work in IR theory. Our primary purpose has not been to endorse a specific philosophy of history. Instead, our aim has been more basic, and indeed more radical. We call attention to a fundamental pluralism already entrenched in the discipline. That pluralism is reflected in the field's nascent return to theories of history, in the multiple forms we indicate above. This theoretical turn should be made more explicit and systematic, and should embrace the pluralism we document, taking in a full range of historicaltheoretic traditions. Contra the field's putative recent turn away from metatheoretical concerns, we call for greater attention to an area of essentially philosophical concern. This article is thus a call to arms - for more plural and more philosophically and historically sophisticated IR theory across all schools of thought.

We note especially the recent increase in multilinear approaches. Whether they view history as familiar and unfamiliar, these accounts themselves take pluralism seriously, building multiple experiences of the past into their worldviews. This pluralism - whether in the form of attention to the diversity of historical international systems, or to the disparate and diverse viewpoints from which history has been lived - reflects the increasing status of IR as a global discipline. This global diversity should, we think, be both celebrated and better understood. Attention to the historical-theoretic roots of these approaches can aid the discipline in so doing.

It is not coincidental to the internal pluralism of multilinear approaches that some of these are today among the most historical-theoretically selfaware in the field. This theoretical self-awareness stands as an example for IR theorists of all stripes - not to fundamentally revise their views about history, but to make them more explicit. Such explicit self-awareness will make contention between schools over the nature and knowability of history more useful and equitable. For example, visions of the arc of history

59 As Widmaier (2004) notes, theories (including theories of history) imply political projects, a prospect of which these pluralist theorists are well aware. 
'as long and bending toward liberty', or as a persistent source of cyclical injustice or violence, should be detailed and defended full-throatedly, not taken for granted. Claims about globalization as convergence or persistent pluralism should be understood as locating the futures they imagine in historical-theoretic context. Fifty years ago, Wight $(1966,33)$ suggested that 'there is no international theory except the kind of rumination about human destiny to which we give the unsatisfactory name of philosophy of history'. We argue such historical theorizing need not be, indeed should not be, unsatisfactory: it offers a way forward in reorienting the field's theoretical precepts. Doing so stands to make the field both more plural and more productive.

\section{Acknowledgments}

The authors would like to thank Andreas Behnke, Andrew Hom, Seth Jaffe, David Polansky, Simon Pratt, and participants in a panel at the 2013 ISA - Northeast Annual Meeting in Providence, RI, as well as three very helpful anonymous reviewers and the journal's editors.

\section{References}

Abbott, Andrew. 2001. Time Matters: On Theory and Method. Chicago, IL: University of Chicago Press.

Acharya, Amitav. 2014. "Global International Relations (IR) and Regional Worlds." International Studies Quarterly 58(4):647-59.

Ackerly, Brooke, and Jacqui True. 2008. "An Intersectional Analysis of International Relations: Recasting the Discipline." Politics \& Gender 4(1):156-73.

Adler, Emanuel. 1991. "Cognitive Evolution: A Dynamic Approach for the Study of International Relations and Their Progress." In Progress in Postwar International Relations, edited by Emanuel Adler, and Beverly Crawford, 43-88. New York: Columbia University Press.

Angell, Norman. 1972. The Great Illusion, 1933. New York: Arno Press.

Aron, Raymond. 1976. Introduction to the Philosophy of History: An Essay on the Limits of Historical Objectivity. Boston, MA: Greenwood Press.

Ashley, Richard K. 1986. "The Poverty of Neorealism.” In Neorealism and its Critics, edited by Robert O. Keohane, 255-300. New York: Columbia University Press.

Axelrod, Robert. 1984. The Evolution of Cooperation. New York: Basic Books.

Bacon, Francis. 2001 [1605]. In The Advancement of Learning, edited by G. W. Kitchin, and Jerry Weinberger, Philadelphia, PA: Paul Dry Books.

Barkawi, Tarak, and Mark Laffey. 2006. "The Postcolonial Moment in Security Studies." Review of International Studies 32(2):329-52.

Bartelson, Jens. 1995. A Genealogy of Sovereignty. Cambridge: Cambridge University Press.

Baylis, John, Steve Smith, and Patricia Owens. 2010. The Globalization of World Politics: An Introduction to International Relations. Oxford: Oxford University Press.

Beiner, Ronald. 2014. Political Philosophy: What it is and Why it Matters. Cambridge: Cambridge University Press. 
Benardete, Seth. 1999. Herodotean Inquiries. South Bend, IN: St. Augustine's Press.

Berenskoetter, Felix. 2011. "Reclaiming the Vision Thing: Constructivists as Students of the Future." International Studies Quarterly 55(3):647-68.

Bukovansky, Mlada. 2002. Legitimacy and Power Politics: The American and French Revolutions in International Political Culture. Princeton, NJ: Princeton University Press.

Butterfield, Herbert. 1965. The Whig Interpretation of History. New York: Norton.

Buzan, Barry. 2004. From International to World Society?: English School Theory and the Social Structure of Globalisation. Cambridge: Cambridge University Press.

Buzan, Barry. 2014. An Introduction to the English School of International Relations: The Societal Approach. Cambridge: Polity Press.

Buzan, Barry, and Richard Little. 2000. International Systems in World History: Remaking the Study of International Relations. Oxford: Oxford University Press.

Buzan, Barry, and George Lawson. 2013. "The Global Transformation: The Nineteenth Century and the Making of Modern International Relations." International Studies Quarterly 57(3):620-34.

Buzan, Barry, and George Lawson. 2015. The Global Transformation: History, Modernity and the Making of International Relations. Cambridge: Cambridge University Press.

Carr, Edward Hallett. 1945. Nationalism and After. London: Macmillan.

Carr, Edward Hallett. 2001a. The Twenty Years' Crisis, 1919-1939, 2nd ed. New York: Perennial.

Carr, Edward Hallett. 2001b. What is History? London: Palgrave.

Checkel, Jeffrey T. 1998. "The Constructive Turn in International Relations Theory.” World Politics 50(2):324-48.

Collingwood, Robin George. 1994. The Idea of History: With Lectures 1926-1928, Revised ed. Oxford: Oxford Paperbacks.

Cox, Robert W. 1986. "Social Forces, States and World Orders." In Neorealism and its Critics edited by Robert O. Keohane, 204-254. New York, NY: Columbia University Press.

Der Derian, James, and Michael J. Shapiro. eds. 1989. International/Intertextual Relations: Postmodern Readings of World Politics. Lexington, MA: Lexington Books.

Deutsch, Karl W. 1966. "The Future of World Politics.” The Political Quarterly 37(1):9-32.

Donnelly, Jack. 2009. "Rethinking Political Structures: From 'Ordering Principles' to 'Vertical Differentiation'-and Beyond.” International Theory 1(1):49-86.

Doyle, Michael W. 1983. "Kant, Liberal Legacies, and Foreign Affairs." Philosophy \& Public Affairs 12(3):205-35.

Dray, William H. ed. 1966. Philosophical Analysis and History. New York: Harper \& Row.

Dugin, Alexander. 2012. The Fourth Political Theory. London: Arktos.

Fearon, James D., and Alexander Wendt. 2002. "Rationalism Vs. Constructivism: A Skeptical View." In Handbook of International Relations, edited by Walter Carlsnaes, Thomas Risse, and Beth A. Simmons, 52-72. London: SAGE.

Fortin, Ernest L. 1979. "Augustine's City of God and the Modern Historical Consciousness." The Review of Politics 41(3):323-43.

Foucault, Michel. 1980. Power/Knowledge: Selected Interviews and Other Writings, 1972-1977. New York, NY: Pantheon Books.

Fukuyama, Francis. 1992. End of History and the Last Man. New York: The Free Press.

Gadamer, Hans-Georg. 2000. The Beginning of Philosophy. Cambridge, MA: Continuum.

Gilpin, Robert. 1983. War and Change in World Politics. Cambridge: Cambridge University Press.

Glock, Hans-Johann. 2008. “Analytic Philosophy and History: A Mismatch?” Mind 117(468):867-97. 
Gong, Gerrit W. 1984. The Standard Of 'Civilization' in International Society. Oxford: Clarendon Press.

Gould, Stephen Jay. 1987. Time's Arrow, Time's Cycle: Myth and Metaphor in the Discovery of Geological Time. Cambridge, MA: Harvard University Press.

Haas, Ernst B. 1991. When Knowledge is Power: Three Models of Change in International Organizations. Berkeley, CA: University of California Press.

Haas, Ernst B. 1997. Nationalism, Liberalism, and Progress: The Rise and Decline of Nationalism, vol. 1. Ithaca, NY: Cornell University Press.

Hall, Rodney Bruce. 1999. National Collective Identity: Social Constructs and International Systems. New York: Columbia University Press.

Hansen, Lene. 2006. Security as Practice: Discourse Analysis and the Bosnian War. Abingdon, Oxon: Routledge.

Healy, Kiran. Forthcoming. "Fuck Nuance." Sociological theory. Available at https://kier anhealy.org/files/papers/fuck-nuance.pdf

Hegel, Georg Wilhelm Friedrich. 1967. Philosophy of Right. Translated by T. M. Knox. London: Oxford University Press.

Hegel, Georg Wilhelm Friedrich. 1988. Introduction to the Philosophy of History. Indianapolis: Hackett Publishing.

Hegel, Georg Wilhelm Friedrich. 2003. The Phenomenology of Mind. Translated by J. B. Baillie. London: Dover.

Heidegger, Martin. 1962. Being and Time. Translated by John Macquarrie and Edward Robinson. New York: Harper \& Row.

Herodotus. 2010. The History, edited by David Grene. Chicago, IL: University of Chicago Press. Hobbes, Thomas. 1989. "To the Readers" In The Peloponnesian War, by Thucydides, edited by David Grene, translated by Thomas Hobbes. Chicago, IL: University of Chicago Press, xxi-xxiv.

Hobden, Stephen, and John M. Hobson. eds. 2002. Historical Sociology of International Relations. Cambridge: Cambridge University Press.

Hobson, John M., and George Lawson. 2008. "What is History in International Relations?" Millennium - Journal of International Studies 37(2):415-35.

Hom, Andrew R. 2010. "Hegemonic Metronome: The Ascendancy of Western Standard Time." Review of International Studies 36(4):1145-170.

Hornblower, Simon. 1991. A Commentary on Thucydides, vol. 1. Oxford: Clarendon Press.

Hui, Victoria Tin-bor. 2005. War and State Formation in Ancient China and Early Modern Europe. Cambridge: Cambridge University Press.

Husserl, Edmund. 1970. The Crisis of European Sciences and Transcendental Phenomenology; an Introduction to Phenomenological Philosophy. Evanston, IL: Northwestern University Press.

Hutchings, Kimberly. 2007. "Happy Anniversary! Time and Critique in International Relations Theory." Review of International Studies 33(Supplement S1):71-89.

Hutchings, Kimberly. 2008. Time and World Politics: Thinking the Present. Manchester: Manchester University Press.

Inayatullah, Naeem, and David L. Blaney. 2003. International Relations and the Problem of Difference. London: Routledge.

Jackson, Patrick Thaddeus. 2011. The Conduct of Inquiry in International Relations: Philosophy of Science and its Implications for the Study of World Politics, 1st ed. London: Routledge. 
Jackson, Patrick Thaddeus, and Daniel H. Nexon. 2013. "International Theory in a PostParadigmatic Era: From Substantive Wagers to Scientific Ontologies.” European Journal of International Relations 19(3):543-65.

Jervis, Robert. 1991. "The Future of World Politics: Will it Resemble the Past?” International Security 16(3):39-73.

Kang, David C. 2010. East Asia Before the West: Five Centuries of Trade and Tribute. New York: Columbia University Press.

Kant, Immanuel. 1991. "Idea for a Universal History with a Cosmopolitan Purpose.” In Political Writings, 2nd ed., edited by H. S. Reiss, translated by H. B. Nisbet, 51-53. Cambridge: Cambridge University Press.

Katzenstein, Peter J. ed. 2009. Civilizations in World Politics: Plural and Pluralist Perspectives. London: Routledge.

Keck, Margaret E. 1998. Activists Beyond Borders: Advocacy Networks in International Politics. Ithaca, NY: Cornell University Press.

Keene, Edward. 2014. "The Standard of 'Civilisation', the Expansion Thesis and the 19th-Century International Social Space.” Millennium - Journal of International Studies 42(3):651-73.

Kennan, George F. 2012. American Diplomacy. 60th-anniversary expanded ed. Chicago, IL: University of Chicago Press.

Keohane, Robert O. 1984. After Hegemony: Cooperation and Discord in the World Political Economy. Princeton, NJ: Princeton University Press.

Krasner, Stephen D. 1999. Sovereignty: Organized Hypocrisy. Princeton, NJ: Princeton University Press.

Kratochwil, Friedrich. 2006. "History, Action and Identity: Revisiting the 'Second' Great Debate and Assessing its Importance for Social Theory." European Journal of International Relations 12(1):5-29.

Kropotkin, Piotr Alekseevich. 1995. Kropotkin: 'The Conquest of Bread' and Other Writings. Cambridge: Cambridge University Press.

Kuhn, Thomas S. 1996. The Structure of Scientific Revolutions, 3rd ed. Chicago, IL: University of Chicago Press.

Lake, David A. 2011. "Why 'isms' Are Evil: Theory, Epistemology, and Academic Sects as Impediments to Understanding and Progress." International Studies Quarterly 55(2):465-80.

Lawson, George. 2010. "The Eternal Divide? History and International Relations.” European Journal of International Relations 18(2):203-26.

Lebow, Richard Ned. 2009. A Cultural Theory of International Relations. Cambridge: Cambridge University Press.

Lenin, Vladimir Ilyich. 1987. Essential Works of Lenin: “What Is to Be Done?" and Other Writings. Henry M. Christman, ed. New York, NY: Dover.

Levine, Daniel J., and Alexander D. Barder. 2014. "The Closing of the American Mind: 'American School' International Relations and the State of Grand Theory." European Journal of International Relations 20(4):863-88.

Löwith, Karl. 1957. Meaning in History: The Theological Implications of the Philosophy of History. Chicago, IL: University of Chicago Press.

Lundborg, Tom. 2012. Politics of the Event: Time, Movement, Becoming. London: Routledge.

Lyotard, Jean Francois. 1984. The Postmodern Condition: A Report on Knowledge. Minnesota, MN: University of Minnesota Press.

Machiavelli, Niccolò. 2009. Discourses on Livy. Chicago, IL: University of Chicago Press.

MacKay, Joseph. 2016. "The Nomadic Other: Ontological Security and the Inner Asian Steppe in Historical East Asian International Politics.” Review of International Studies 42(3):471-91. 
MacKay, Joseph, and Jamie Levin. 2015a. "Hanging Out in International Politics: Two Kinds of Explanatory Political Ethnography for IR.” International Studies Review 17(2):163-88.

MacKay, Joseph, and Jamie Levin. 2015b. A Hegelian Realist Constructivist Account of War, Identity, and State Formation. Journal of International Relations and Development (2), https://doi.org/10.1057/jird.2015.24.

MacMillan, Margaret. 2001. Paris 1919: Six Months That Changed the World. New York: Random House.

Manent, Pierre. 1994. An Intellectual History of Liberalism. Translated by Rebecca Balinski. Princeton, NJ: Princeton University Press.

Mansfield, Harvey C. 1996. Machiavelli's Virtue. Cambridge: Cambridge University Press.

Marx, Karl, and Friedrich Engels. 1992. The Communist Manifesto. Oxford: Oxford University Press.

McIntosh, Christopher. 2015. "Theory Across Time: The Privileging of Time-Less Theory in International Relations." International Theory 7(3):464-500.

Mearsheimer, John J. 1994. "The False Promise of International Institutions." International Security 19(3):5-49.

Mearsheimer, John J. 2003. The Tragedy of Great Power Politics. New York: Norton.

Mingst, Karen A., and Ivan Arreguín-Toft. 1999. Essentials of International Relations. New York: Norton.

Mitzen, Jennifer. 2013. Power in Concert: The Nineteenth-Century Origins of Global Governance. Chicago, IL: University of Chicago Press.

Modelski, George. 1978. "The Long Cycle of Global Politics and the Nation-State." Comparative Studies in Society and History 20(2):214-35.

Molloy, Seán. 2006. The Hidden History of Realism: A Genealogy of Power Politics. New York, NY: Palgrave Macmillan.

Morgenthau, Hans J. 1946. Scientific Man Vs. Power Politics. Chicago, IL: University of Chicago Press.

Morgenthau, Hans J. 1948. Politics Among Nations: The Struggle for Power and Peace. New York: Knopf.

Morgenthau, Hans J. 2004. Political Theory and International Affairs: Hans J. Morgenthau on Aristotle's The Politics. Edited by Anthony F. Lang Jr. Westport, CT: Greenwood Publishing Group.

Musgrave, Paul, and Daniel H. Nexon. 2013. "Singularity or Aberration? A Response to Buzan and Lawson.” International Studies Quarterly 57(3):637-39.

Nexon, Daniel H. 2009. The Struggle for Power in Early Modern Europe: Religious Conflict, Dynastic Empires, and International Change. Princeton, NJ: Princeton University Press.

Niebuhr, Reinhold. 2008. The Irony of American History. Chicago, IL: University of Chicago Press.

Nietzsche, Friedrich. 1967. The Birth of Tragedy and the Case of Wagner. New York, NY: Random House LLC.

Nietzsche, Friedrich. 1980. On the Advantage and Disadvantage of History for Life. Indianapolis, IN: Hackett Publishing.

Nietzsche, Friedrich. 2003. On the Genealogy of Morality, edited by Keith Ansell Pierson, translated by Carol Diethe. Cambridge: Cambridge University Press.

Oakeshott, Michael. 1999. On History and Other Essays. Indianapolis, IN: Liberty Fund.

Odysseos, Louiza, and Fabio Petito. eds. 2007. The International Political Thought of Carl Schmitt: Terror, Liberal War and the Crisis of Global Order. Abingdon, Oxon: Routledge.

Onuf, Nicholas Greenwood. 1989. World of Our Making: Rules and Rule in Social Theory and International Relations. Columbia, SC: University of South Carolina Press. 
Osterhammel, Jürgen. 2014. The Transformation of the World: A Global History of the Nineteenth Century. Translated by Patrick Camiller. Princeton, NJ: Princeton University Press.

Phillips, Andrew, and Jason C. Sharman. 2015. International Order in Diversity: War, Trade and Rule in the Indian Ocean. Cambridge: Cambridge University Press.

Philpott, Daniel. 2001. Revolutions in Sovereignty: How Ideas Shaped Modern International Relations. Princeton, NJ: Princeton University Press.

Pocock, John Greville Agard. 1971. Politics, Language, and Time: Essays on Political Thought and History. Chicago, IL: University of Chicago Press.

Pomeranz, Kenneth. 2009. The Great Divergence: China, Europe, and the Making of the Modern World Economy. Princeton, NJ: Princeton University Press.

Reus-Smit, Christian. 1999. The Moral Purpose of the State: Culture, Social Identity, and Institutional Rationality in International Relations. Princeton, NJ: Princeton University Press.

Reus-Smit, Christian. 2008. "Reading History Through Constructivist Eyes." Millennium Journal of International Studies 37(2):395-414.

Ricoeur, Paul. 1965. History and Truth. Evanston, IL: Northwestern University Press.

Risse, Thomas, Steve C. Ropp, and Kathryn Sikkink. 1999. The Power of Human Rights: International Norms and Domestic Change. Cambridge: Cambridge University Press.

Roberts, Geoffrey. 2006. "History, Theory and the Narrative Turn in IR." Review of International Studies 32(4):703-14.

Rosenberg, Justin. 2006. "Why is There No International Historical Sociology?" European Journal of International Relations 12(3):307-40.

Ruggie, John G. 1986. "Continuity and Transformation in the World Polity: Toward a Neorealist Synthesis." In Neorealism and its Critics, edited by Robert O. Keohane, 131-57. New York: Columbia University Press.

Said, Edward W. 1979. Orientalism. New York, NY: Random House LLC.

Sens, Allen Gregory, and Peter John Stoett. 2002. Global Politics: Origins, Currents, Directions. Toronto: Nelson Thomson Learning.

Sil, Rudra, and Peter Katzenstein. 2010. Beyond Paradigms: Analytic Eclecticism in the Study of World Politics. New York, NY: Palgrave Macmillan.

Sjoberg, Laura. 2012. “Gender, Structure, and War: What Waltz Couldn't See.” International Theory 4(1):1-38.

Skinner, Quentin. 1969. "Meaning and Understanding in the History of Ideas." History and Theory 8(1):3-53.

Smith, Thomas W. 2004. History and International Relations. London: Routledge.

Solomon, Ty. 2014. "Time and Subjectivity in World Politics." International Studies Quarterly 58(4): 671-81.

Stockdale, Liam P. D. 2015. Taming an Uncertain Future: Temporality, Sovereignty, and the Politics of Anticipatory Governance. Lanham: Rowman \& Littlefield International.

Strauss, Leo. 2013. On Tyranny: Including the Strauss-Kojève Correspondence. Chicago, IL: University of Chicago Press.

Suzuki, Shogo. 2009. Civilization and Empire: China and Japan's Encounter With European International Society. London: Routledge.

Tarcov, Nathan. 1983. "Philosophy \& History: Tradition and Interpretation in the Work of Leo Strauss." Polity 16(1):5-29.

Taylor, Charles. 1985. "Interpretation and the Sciences of Man." Philosophy and the Human Sciences: Philosophical Papers 2. Cambridge: Cambridge University Press, 15-57. 
Thomas, Pangle and Peter Ahrensdorf. 1999. Justice Among Nations: On the Moral Basis of Power and Peace. Lawrence, KS: University Press of Kansas.

Thucydides. 1998. The Peloponnesian War. Indianapolis, IN: Hackett.

Tickner, J. Ann. 1997. "You Just Don't Understand: Troubled Engagements Between Feminists and IR Theorists." International Studies Quarterly 41(4):611-32.

Toynbee, Arnold J. 1934. A Study of History, 12 vols. Oxford: Oxford University Press.

Tucker, Aviezer. ed. 2009. A Companion to the Philosophy of History and Historiography. Malden, MA: Wiley-Blackwell.

Vašíček, Zdeněk. 2009. "Philosophy of History.” In A Companion to the Philosophy of History and Historiography, edited by Aviezer Tucker, 26-43. Malden, MA: Wiley-Blackwell.

Vaughan-Williams, Nick. 2005. "International Relations and the 'Problem of History." Millennium - Journal of International Studies 34(1):115-36.

Voegelin, Eric. 1987. The New Science of Politics. Chicago, IL: University of Chicago Press.

Vrasti, Wanda. 2008. "The Strange Case of Ethnography and International Relations." Millennium - Journal of International Studies 37(2):279-301.

Waever, Ole. 2009. "Waltz's Theory of Theory.” International Relations 23(2):201-22.

Walker, Robert B. J. 1993. Inside/Outside: International Relations as Political Theory. Cambridge: Cambridge University Press.

Wallerstein, Immanuel. 1979. The Capitalist World Economy. Cambridge: Cambridge University Press.

Waltz, Kenneth N. 1959. Man, the State, and War: A Theoretical Analysis. Chicago, IL: Columbia University Press.

Waltz, Kenneth N. 1979. Theory of International Politics. New York: McGraw-Hill.

Waltz, Kenneth N. 1997. "Evaluating Theories." American Political Science Review 91(4): 913-17.

Welch, David A. 2003. "Why International Relations Theorists Should Stop Reading Thucydides." Review of International Studies 29(3):301-19.

Wendt, Alexander. 1992. "Anarchy is What States Make of it: The Social Construction of Power Politics.” International Organization 46(2):391-425.

Wendt, Alexander. 1999. Social Theory of International Politics. Cambridge: Cambridge University Press.

Wendt, Alexander. 2003. "Why a World State is Inevitable." European Journal of International Relations 9(4):491-542.

Widmaier, Wesley W. 2004. "Theory as a Factor and the Theorist as an Actor: The 'Pragmatist Constructivist' Lessons of John Dewey and John Kenneth Galbraith.” International Studies Review 6(3):427-45.

Wight, Martin. 1966. "Why is There No International Theory?.” In Diplomatic Investigations: Essays in the Theory of International Politics, edited by Herbert Butterfield, and Martin Wight, 17-34. Cambridge, MA: Harvard University Press.

Wight, Martin. 1977. Systems of States. Edited by Hedley Bull. Leicester, UK: Leicester University Press.

Wight, Martin. 1992. International Theory: The Three Traditions. New York: Holmes \& Meier.

Williams, Michael C. 2005. The Realist Tradition and the Limits of International Relations. Cambridge: Cambridge University Press. 